\title{
SERUM FERRITIN AND HCV INFECTION IN NIGERIAN PATIENTS WITH PRIMARY LIVER CELL CARCINOMA
}

\author{
'Ola, S.O., ${ }^{2}$ Odaibo, G.N
}

Departments of ${ }^{1}$ Medicine and ${ }^{2}$ Virology, College of Medicine, University of Ibadan, University College Hospital, Ibadan; Nigeria.

Correspondence:- Dr S.O. Ola, Email-address: soola@comui.edu.ng

\begin{abstract}
A prospective study aimed at determining the relationship between hepatitis $\mathrm{C}$ virus (HCV) infection and serum ferritin in Nigerian patients with primary liver cell carcinoma (PLCC) was carried out at the University College Hospital (UCH), Ibadan; Nigeria. The study involved 42 adult Nigerians made up of 14 healthy subjects as controls and 14 patients each with PLCC and liver cirrhosis (LC) who consented to participate in the study. The subjects were controlled for age and sex. The diagnosis of the diseases was made from relevant clinical features, ultrasonography and histology of liver biopsy specimen. Blood specimen collected from the subjects were analysed for ferritin by radio-immuno assay using Amersham Kits, hepatitis B virus (HBV) infection using HBsAg detection and anti-HCV by ELISA (Sanofi Pasteur. France). The study protocol was approved by the Joint UI/UCH Ethical Review Board. Data otained was analysed with the SSPS software at a level of significance of $p<0.05$. Serum ferritin $>700 \mathrm{ng} / \mathrm{ml}$ was detected only in $50 \%$ and $14 \%$ of the patients with PLCC and LC respectively with specificity of $93 \%$ as well as negative $(\mathbf{7 8 \%})$ and positive $(\mathbf{7 9} \%)$ predictive values. Serum anti-HCV and HBsAg were present in $14 \%$ and $71 \%$ of patients with PLCC respectively $(p<0.005)$. Similarly, $29 \%$ and $14 \%$ of the patients and the Controls respectively were sero-positive for anti $\mathrm{HCV}$ while serum HBsAg was detected in equal proportions of the patients with LC $(50 \%)$ and the Controls $(43 \%)$. There was correlation between elevated serum ferritin and $\mathrm{HBsAg}\left(\mathrm{X}^{2}\right.$ with Yates correction $\left.=5.04, p=0.025\right)$ but none with serum anti-HCV.

In conclusion, the study shows that serum ferritin level $\geq 700 \mathrm{ng} / \mathrm{ml}$ is indicative of PLCC among Nigerians especially in the presence of $\mathrm{HBV}$ infection but may not be useful when there is associated $\mathrm{HCV}$ infection.
\end{abstract}

\section{Introduction}

Hepatitis C virus (HCV) infection occurs globally(1). It presents more with asymptomatic course resulting in chronic hepatitis and later progressing to primary liver cell carcinoma (FLCC). Although, PLCC has been associated -re with hepatitis B virus infection in Nigeria 2 ). may assume increasing trends once iz:- $\quad$ rainst HBV becomes efficient as in - : es $(3,4)$. Hence, HCV infection

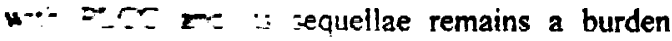
since there $\div$ rose $\because \cdots$ vocine against the virus. Efforts directed $z$ tearer: $\mathrm{PLCC}$ have been met with poor success because of the late presentation of the patients at hospitals(5). Early diagnosis of the disease is therefore necessary. To ensure this, various tumour markers have been shown to be useful in the diagnosis of PLCC among different populations(6,7). Specifically, serum ferritin has been documented to be a useful marker in diagnosis of PLCC among Nigerians(8). The significance of serum ferritin in the presence of HCV infection remains unknown. This study was designed to determine the level of serum ferritin in Nigerian patients with primary liver cell 
cateinoma (PLCC) especially when thete is associated hepatitis $\mathrm{C}$ vitus infection.

\section{Materials and Methods}

Forty-two adult Nigetian subjects wete fectuited into the study after obtaining informed consent. The subjects comprised 14 appatently healthy adults as cortitfol (group 1) and 14 patients each with livet eitrhosis-LC (group II) and PLCC (group III). They wete sex and age matched. There was no ingestion of multivitamin medication. obvious blood loss of blood transfusion in any of the subject within 12 months prior their inclusion in the study. In addition, ho subject was anaemic at entry into the study. Relevant clinical features. ultrasonography and histology of liver biopsy specimen wete utilised to make the diagnosis of both LC and PLCC. Blood specimens mee collected from the subjects for cracked ce" vime (PCV) estimation. sercamalys's of rem. '.ue

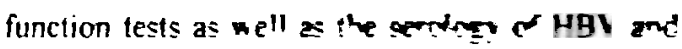

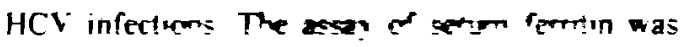
cartied on by ratermmone assay using Amerstrger Kes (Ferren RIA Kit. IM 1051). The sefum HQS A ( $\mathrm{HBV}$ infection) and anti-HCV were determined ty ELISA. Livet function tests werc measured in all patients by toutine laboratory methons

The study $m$ as carricd out aftet obtaining clearance from Ionnt LI LCH Ethical Review Board. The SPSS statsical package was utilized for data entries and analysis on a micto-computer. The Kruskal Wallis statistics. a non parametric equivalem of the analysis of vartance technique and the Mant Whitncy $U$ test, a notn parametric cquivalent of the student's t-test were used to compare the means of values of continuous variables. The Chi-square test and Fisher's exact test wete used to determine the statistical signific nce of the association between two categorical variables. The validity of the diagnostic value of fertitin for PLCC was also examined by calculating the setisitivity, specifieity, positive and negative predictive values whete the histological finditigs wete the gold standard: All statistical analysis wete cattied out at $5 \%$ probability level.

\section{Results}

The forty-two 42 subjects studied wefe made up of controls (14) and patietits with PLCC (14) and LC (14). They were $48 \pm 14,49 \pm 15$, and $55 \pm 12$ vears of age respectively. Each gtoup had male female ratio of 11:3. The Child Pugh stages of the patiems in both PLCC and LC were similat (4 and 10 patiems in each group wete scoted $A$ antd $B$ respectively). The $\mathrm{PCV}$ in the subjects wete $43 \pm 4 \% 38 \pm \%$ and $33 \ldots-\%$ for the control subjects and the crots wh PLCC and LC tespectively. Tie piv among the control subjects was sErem!y moter than the value for either the remes with PLCC $(P<0.05)$ of LC $(p<0.001)$. Serum fertitin $>700$ tig/til was detected in $50 \%$ of the patients with PLCC (specificity, negative and positive predictive values were $93 \%, 78 \%$, and $79 \%$ respectively, Table 1) compated to only $14 \%$ of the patients with LC and nothe of the Controls who had values setum fettititi above the cut-off level. $p<0.05$ each. Setum anti $\mathrm{HCV}$ and HBsAg were present in $14 \%$ and $71 \%$ of patients with PLCC respectively ( $p<0.005$; Table II). Similafly; scrum anti-HCV was present in $29 \%$ and $14 \%$ of the patients with LC and controls respectively whilc setum HBsAg was detected in equal ptopottions of the patients with LC $(50 \%)$ and the Controls $(43 \%)$. Elevated setum fetritin coffelated with seturti $\mathrm{HBsAg}\left(X^{2}\right.$ with Yates cotrection = 5.04, $p=0.025$ ) but not with setum anti-HCV. Among all the subjects studied, 2 patients each with PLCC and LC had co-infection of $\mathrm{HBV}$ and HCV with the fortief patients also having elev ated setum fertitin levels. 
Table I. The validity of serum ferritin in diagnosing PLCC among adult Nigerian patients at different cut-off points.

Validity(\%)

\begin{tabular}{lcccccl}
\hline Ferritin (ug/L) & positive & negative & Sen. & Spec. & PPV & NPV \\
\hline$\geq 700$ & 7 & 2 & 50 & 93 & 78 & 79 \\
$<700$ & 7 & 26 & & & & \\
\hline$\geq 600$ & 7 & 6 & 50 & 78 & 54 & 76 \\
$<600$ & 7 & 22 & & & & \\
\hline$\geq 800$ & 6 & 2 & 43 & 93 & 75 & 76 \\
$<800$ & 8 & 26 & & & & \\
\hline
\end{tabular}

$\%$ - percentage Sen. - Sensitivity Spec. - Specificity

PPV - Positive Predictive Value NPV - Negative Predictive Value

PLCC - Primary Liver Cell carcinoma

Table II The association between serum ferritin. HBV and $\mathrm{HCV}$ in adult Nigerian patients with PLCC, $\mathrm{LC}$ and contrels

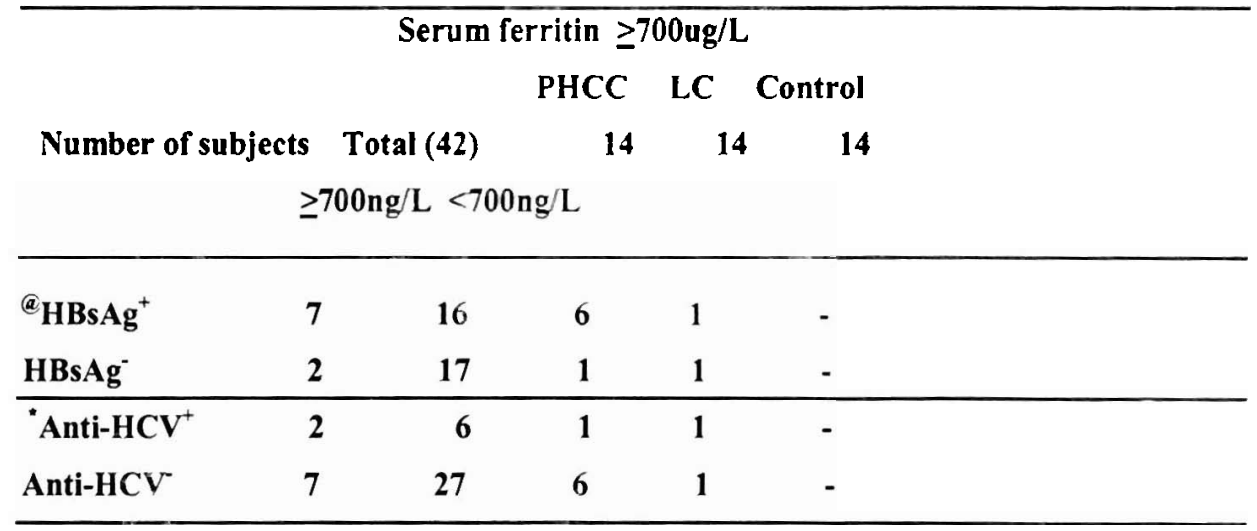

(a) $\mathrm{X}^{2}$ with Yates correction $=\mathbf{5 . 0 4}, \mathrm{p}=\mathbf{0 . 0 2 5}$ for Ferritin \& HBsAg in PLCC *P=0.64 for ferritin \& HCV in PLCC PLCC - Primary liver cell carcinoma, LC - Liver Cirrhosis HBV - Hepatitis B Virus HCV - Hepatitis C Virus HbsAg - Hepatitis B surface Antigen 


\section{Discussion}

Elevated serum ferritin level has been reported to be diagnostic of PLCC in different populations including Nigerians $(6,8)$. This study has taken into consideration the role of blood loss, infectious anemia as well as ingestion of iron tablets on serum ferritin level hence the packed cell volume of the subjects studied are not unexpected. The serum ferritin level of $\geq 700 \mathrm{ug} / \mathrm{L}$ as diagnostic level for PLCC is a better discriminatory level for the tumour from liver cirrhosis than the value of 400ug/L earlier reported among Nigerian(8). High serum ferrittin levels in our patients with PLCC might be due to the production of ferritin by the tumour rather than to liver necrosis(9). Although, at serum ferritin level of $\geq 700 \mathrm{ug} / \mathrm{L}$, two of our patients with LC were shown to have elevated levels of serum ferritin which may be suggestive of occult PLCC. This shows the limitation of histological diagnosis in absence of screening with a tumour market. It is however comparable to the report among Europeans (10).

In view of the vary proportions of our pariems nith PLCC having HBV and HCV infections, bath viruses could have contributed to the aetiology of the disease. Despite the use of ELISA for asy of HBsAg in our study, the correlation observed between elevated level of serum ferritin corroborates previous reports where heamaglution method had been utilized for the detection of serum HBsAg(8). This also shows that serum level of ferritin $\geq 700 \mathrm{ng} / \mathrm{ml}$ is diagnostic of PLCC especially in the presence of $\mathrm{HBV}$ infection. It suggests that serum level of ferritin in patients with PLCC may be influenced by HBV infection since the virus gets intercalated with the hepatocellular DNA in aetio-pathogenesis of the tumour. In view of the diverse aetiological factors for PLCC, there is the need to define the effects of the other causal factors like $\mathrm{HCV}$ on the expression of the markers that may aid diagnosis of the tumour(11). In spite of the worldwide prevalence of $\mathrm{HCV}$ infection and its relationship to PLCC, the association between serum ferritin and $\mathrm{HCV}$ infection has hitherto remained unknown among Nigerians. However, our study has shown that there is absence of correlation between elevated serum levels of ferritin and $\mathrm{HCV}$ infection in Nigerian patients with PLCC. This observation might not be unconnected with the predominantly chronic clinical course and pathology of $\mathrm{HCV}$ infection(12). The presence of elevated level of serum ferritin among the two patients who had combined infection of HBV and HCV could be due to the effects of HBV. However, further study involving a larger sample size will be necessary to elucidate this observation.

In conclusion, this study shows that serum ferritin level $\geq 700 \mathrm{ng} / \mathrm{ml}$ is diagnostic of PLCC among Nigerians. In addition. setum ferritin may not be useful in screening for PLCC among Nigerians with $\mathrm{HCV}^{-}$infection but the converse holds for those infected with HBV.

\section{References}

1. Strickland G.T. Hepatitis $C$ in developing countries. Postgraduate Doct. Afri. 2002; 24: 26-28.

2. Olubuyide I.O., Aliyu B. Olaleye O.A., Ola S.O. Olawuyi F. Malabu. U.H. et al.: Hepatitis B and C virus and Hepatocellular Carcinoma;

Trans. Roy. Soc. Trop. Med. Hyg., 1997; 91: 38-41.

3. Raptis I, Koskinas J, Emmanouil T, Hadziyannis S. Changing relative roles of hepatitis $B$ and $C$ viruses in the aetiology of hepatocellular carcinoma in Greece. Epidemiological and clinical observations.J. Viral Hepat 2003: 10 : 450-4. 
4. Kim WR, Benson JT, Therneau TM, Torgerson HA, Yawn BP, Melton LJ. Changing epidemiology of hepatitis $B$ in a U.S. community. Hepatology. 2004; 39:811-6.

5. Ola S.O. Relief to the Scourge of Hepatocellular Carcinoma. Nigerian Journal of Medicine, 2002; 11:156-160.

6. Warnes T.W., Smith A. Tumour markers in diagnosis and treatment. Bailleres Clin. Gastroent. 1987;1:63-89.

7. Nguyen MH, Keeffe EB. Screening for hepatocellular carcinoma. J Clin Gastroenterol 2002;35:S86-91

8. Ola, S.O. Akanji A.O. Ayoola E.A.: The diagnostic utility of serum ferritin estimation in Nigerian patients with primary hepatocellular carcinoma. Suppliment to Nutrition 1995; 11: 532 534.

9. Sherlock S., Dooley J. Diseases of the Liver and Biliary System. Oxford, Blackwell Science, 2002.

10. Pavesi F, Lotzniker $M$, Scarabelli $M$, Garbagnoli P, Moratti R. Efficiency of composite laboratory tests in the diagnosis of liver malignancies. Int. J. Biol. Markers. 1989; 4: 163-9.

11. Maier KP. [Hepatocellular carcinoma: risk groups--screening] Schweiz Rundsch Med Prax 2002;91:1380-6.

12. Ola S.O., Otegbayo J. A., Odaibo G. N., Olaleye O.D., Olubuyide I.O. Serum hepatitis $C$ virus and hepatitis $B$ surface antigenaemia in Nigerian patients with acute icteric hepatitis. West African Medical Journal 2002; 21:215-217. 